\title{
PENGARUH MODEL PEMBELAJARAN BERBASIS MASALAH TERHADAP HASIL BELAJAR KOGNITIF MATEMATIKA SISWA MTS NEGERI 3 WAKATOBI DI BINONGKO
}

\author{
Lelastri $^{1)}$, Suhar $^{2)}$, Ikman $^{3)}$ \\ 1) Alumni Jurusan Pendidikan Matematika, ${ }^{2,3)}$ Dosen Jurusan Pendidikan Matematika \\ FKIP Universitas Halu Oleo. Email: Lelastri1696@gmail.com; \\ Suhar_fkipmat@gmail.com; ikman_fkipmat@yahoo.com
}

\begin{abstract}
Abstrak
Penelitian ini merupakan penelitian eksperimen. Populasi dalam penelitian ini adalah seluruh siswa kelas VIII MTs Negeri 3 Wakatobi di Binongko yang terdiri dari 3 kelas paralel berjumlah 59 siswa. Penentuan sampel dilakukan dengan teknik class random sampling. Sampel penelitian ini terdiri dari 39 siswa, yang terbagi atas dua kelompok belajar, yaitu kelas VIII $^{1}$ sebagai kelas eksperimen berjumlah 20 siswa dan kelas VIII $^{2}$ sebagai kelas kontrol berjumlah 19 siswa. Data diperoleh menggunakan instrumen berupa tes hasil belajar kognitif matematika siswa. Teknik analisis data menggunakan statistik deskriptif dan statistik inferensial. Hasil penelitian secara deskriptif dan secara inferensial menunjukan bahwa: (1) Rata-rata hasil belajar kognitif matematika siswa yang pembelajaran menggunakan model pembelajaran berbasis masalah adalah 80,42; (2) Rata-rata hasil belajar kognitif matematika siswa yang pembelajaran menggunakan model pembelajaran konvensional adalah 70,03; (3) Pembelajaran dengan menggunakan model pembelajaran berbasis masalah memberikan pengaruh yang signifikan terhadap hasil belajar kognitif matematika siswa kelas VIII MTs Negeri 3 Wakatobi di Binongko.
\end{abstract}

Kata Kunci: model pembelajaran; pembelajaran konvensional; hasil belajar matematika.

\section{THE INFLUENCE OF PROBLEM BASED LEARNING ON MATHEMATICAL COGNITIVE LEARNING OUTCAMES OF STUDENTS OF WAKATOBI MADRASAH TSANAWIYAH NEGERI 3 IN BINONGKO}

\begin{abstract}
Thir research is a quasi experimental.The populasi in this study were all eighth grade students of Madrasah Tsanawiyah Negeri 3 Wakatobi in Binongko which consisted of 3 parallel classes totaling 59 students. Determination of the sample is done by class random sampling technique. The study sample consisted of 39 students, which were divided into two study group, namely class VIII ${ }^{1}$ as an experimental class totaling 20 students. And class VIII ${ }^{2}$ as a control class totaling 19 students. The data analysis technique usesdescriptive statistics and inferential statistics. Descriptive and inferential research result show that: (1) The average cognitive mathematics learning outcomes of students who learn using the problem based learning model is 80,42 ; (2) the average cognitive mathematics learning outcomes of students who learn using convensional learning models is 70,03; (3) Learning using the problem based learning model has a significant influence on the cognitive learning outcomes of mathematics of class VIII Madrasah Tsanawiah Negeri 3 Wakatobi in Binongko.
\end{abstract}

Keywords: learning model; convensional learning; mathematics learning results. 


\section{Pendahuluan}

Matematika memiliki peranan penting terhadap perkembangan ilmu pengetahuan dan teknologi. Hal ini terjadi karena banyak konsep dasar matematika yang digunakan dalam berbagai bidang ilmu pengetahuan dan teknologi saat ini. Oleh karena itu, maka matematika diajarkan disetiap jenjang pendidikan mulai dari sekolah dasar sampai ke perguruan tinggi. Pembelajaran matematika sering kali di pandang sebagai pembelajaran yang hanya terbatas di sekolah dan kurang menyentuh kehidupan sehari-hari. Siswa hanya menghafalkan konsep atau rumus matematika tanpa melihat langsung masalah-masalah yang ada hubungannya dengan konsep tersebut. Keadaan ini sering kali membuat siswa kurang tertarik terhadap pembelajaran yang sedang dipelajari dan cepat bosan hingga akhirnya siswa kurang memahami konsep secara jelas.

Pendidikan formal merupakan amanah untuk mengembangkan sumber daya manusia yang dilakukan secara sistematis, praktis dan berjenjang. Dalam pelaksanaan pembelajaran di sekolah, guru mempunyai peranan yang sangat besar demi tercapainya proses belajar yang baik. Sehubungan dengan peranan ini, guru dituntut untuk memiliki kompetensi yang memadai dalam hal pembelajaran. Rendahnya kompetensi guru menyebabkan pelaksanaan pembelajaran menjadi kurang efektif yang mengakibatkan siswa tidak senang pada pelajaran sehingga mereka dapat mengalami berbagai kesulitan belajar dan prestasi belajarnya pun menurun.

Matematika merupakan mata pelajaran yang mempunyai peranan penting baik penerapannya dalam kehidupan sehari-hari maupun dalam pengembangan ilmu pengetahuan lain. Selain itu keberadaan matematika juga selalu ada disektor kehidupan manusia, karena disadari atau tidak, pada kenyataannya dalam kegiatan sehari- hari tidak terlepas dari peran matematika, hal ini sejalan dengan pendapat Cornelius (dalam Mahendra, 2007) mengatakan bahwa ada banyak alasan tentang perlunya siswa belajar matematika yaitu: (1) merupakan sarana berpikir yang jelas dan logis; (2) sarana memecahkan masalah kehidupan sehari hari; (3) sarana mengenal polapola hubungan dan generalisasi pengalaman; (4) sarana mengembangkan kreativitas; dan (5) sarana untuk meningkatkan kesadaran terhadap perkembangan budaya.
Pembelajaran matematika bagi para siswa merupakan pembentukan pola pikir dalam pemahaman suatu pengertian maupun dalam penalaran suatu hubungan diantara pengertian-pengertian itu. Dalam pembelajaran matematika, para siswa dibiasakan untuk memperoleh pemahaman melalui pengalaman tentang sifat-sifat yang dimiliki dan yang tidak dimiliki dari sekumpulan objek (abstraksi). Siswa diberi pengalaman menggunakan matematika sebagai alat untuk memahami atau menyampaikan informasi misalnya melalui persamaan-persamaan, atau tabel-tabel dalam model-model matematika yang merupakan penyederhanaan dari soal-soal cerita atau soalsoal uraian matematika lainnya. Menurut Hadi (2005) proses pembelajaran matematika yang selama ini terjadi belum sesuai dengan yang diharapkan. Ciri praktik pendidikan selama ini adalah pembelajaran berpusat pada guru. Guru menyampaikan pelajaran dengan menggunakan metode ceremah atau ekspositori, sementara siswa mencatatnya pada buku catatan. Dominasi guru dalam proses pembelajaran menyebabkan kecenderungan siswa lebih bersifat pasif sehingga mereka lebih banyak menunggu sajian guru daripada mencari dan menemukan sendiri pengetahuan, keterampilan atau sikap yang mereka butuhkan.

Berdasarkan hasil Observasi dengan guru mata pelajaran matematika kelas VII MTs Negeri 3 Wakatobi di Binongko, diperoleh hasil belajar kogntif matematika siswa masih rendah. Hal ini dibuktikan dengan penjelasan guru mengenai soal-soal matematika yang berbentuk seperti grafik, diagram maupun soal-soal cerita yang diberikan oleh guru, hanya sekitar 10 orang dari 20 siswa yang mampu menjawab soal-soal jenis tersebut. Berbagai upaya telah dilakukan guru untuk meningkatkan hasil belajar kognitif matematika siswa, seperti mengajar dengan metode membimbing siswa satu persatu di tempat duduk siswa. Tetapi siswa banyak mencari alasan untuk tidak memperhatikan materi yang diajar guru. Dari hasil tersebut dapat dikatakan bahwa hasil belajar kognitif matematika siswa masih rendah. Beberapa faktor penyebab rendahnya hasil belajar matematika siswa diantaranya yaitu: (1) siswa kurang memperhatikan pelajaran khususnya matematika, siswa merasa bosan, malas mengajukan pertanyaan walaupun telah diberikan kesempatan untuk bertanya, malas mengerjakan tugas, siswa tidak mendengarkan 
penjelasan guru justru memilih untuk bercerita dengan teman; (2) kurangnya pemahaman konsep dasar matematika oleh siswa, dikarenakan siswa hanya menghafalkan materi yang diberikan tanpa mencoba mendalami arti dari materi itu, (3) kurangnya sarana dan prasarana dalam kegiatan pembelajaran.

Menurut Dasna dan Sutrisno (2007), salah satu model pembelajaran yang dapat diupayakan untuk mengaktifkan siswa dalam proses belajar mengajar serta upaya pemberian pengalaman belajar yang berkesan bagi siswa adalah pembelajaran berbasis masalah, dimana PBM adalah suatu model pembelajaran yang melibatkan siswa untuk memecahkan suatu masalah melalui tahap-tahap metode ilmiah sehingga siswa dapat mempelajari pengetahuan yang berhubungan dengan masalah tersebut dan sekaligus memiliki ketrampilan untuk memecahkan masalah yang dapat meningkatkan hasil belajar siswa.

Menurut Winkel (2007: 59) menyatakan belajar adalah suatu aktifitas mental/psikis, yang berlangsung dalam interaksi aktif dengan lingkungannya, yang menghasilkan sejumlah perubahan dalam pengetahuan pemahaman, keterampilan dan nilai sikap. Sudjana dalam jihad (2008: 2) menyatakan bahwa belajar adalah suatu proses yang ditandai dengan adanya perubahan pada diri seseorang perubahan sebagai hasil proses belajar dapat ditunjukkan dalam berbagai bentuk. Perubahan memang dapat diamati dan berlaku dalam waktu relatif lama. Perubahan yang relatif lama tersebut disertai dengan berbagai usaha, sehingga Hudoyo (2003: 13) mengatakan belajar itu merupakan suatu usaha yang berupa kegiatan hingga terjadinya perubahan tingkah laku yang relatif lama atau tetap. Ciri-ciri perubahan tingkah laku tersebut meliputi perubahan secara sadar, bersifat kontinyu dan fungsional, positif dan aktif, tidak bersifat sementara dan mencakup seluruh aspek tingkah laku.

Setiap orang dalam mengerjakan sesuatu termasuk kegiatan belajar mengajar selalu menginginkan hasil belajar yang lebih baik. Hal ini, hasil belajar diartikan sebagai suatu kemampuan atau tingkat penguasaan yang dicapai seseorang sebagai akibat dari kegiatan pembelajaran.

Berdasarkan teori Taksonomi Bloom, ada tiga hal ranah hasil belajar, yaitu kognitif, afektif dan psikomotor. Ketiga ranah tersebut menjadi objek penilaian hasil belajar.
Keberhasilan seorang guru diukur dari keterlibatan murid dalam pembelajaran dan hasil belajar yang dicapainya.

Hasil belajar adalah hasil yang dicapai peserta didik melalui proses belajar yang dilakukan peserta didik yang akan menghasilkan perubahan. Perubahan-perubahan ini meliputi bidang atau aspek pengetahuan, perubahan keterampilan, nilai dan sikap, sedangkan hasil belajar dilihat dari nilai tes atau hasil tes (Indriyani, 2011: 15).

Menurut Surya (2017: 43) hasil belajar merupakan tolak ukur untuk melihat keberhasilan peserta didik dalam menguasai materi pelajaran yang disampaikan selama pembelajaran. Hal ini akan ditentukan dengan terjadinya perubahan tingkah laku pada peserta didik setelah proses pembelajaran berakhir.

Hasil belajar adalah suatu proses terjadinya perubahan tingkah laku pada diri siswa, yang dapat diamati dan diukur dalam bentuk perubahan pengetahuan, sikap dan keterampilan. Perubahan itu diartikan terjadinya peningkatan dan pengembangan yang lebih baik dibanding dengan sebelumnya (Hamalik, 2008: 155)

Berdasarkan beberapa pendapat yang telah dikemukakan, dapat disimpulkan bahwa hasil belajar adalah hasil yang dicapai siswa melalui pembelajaran berupa perubahan pengetahuan, keterampilan dan sikap. Jadi hasil belajar matematika merupakan hasil yang dicapai siswa melalui pembelajaran matematika berupa peningkatan penguasaan materi pelajaran matematika. Hal ini dapat diukur melalui nilai hasil tes matematika.

Menurut Tan (Rusman 2010: 232) Pengertian Pembelajaran Berbasis Masalah merupakan penggunaan berbagai macam kecerdasan yang diperlukan untuk melakukan konfrontasi terhadap tantangan dunia nyata, kemampuan untuk menghadapi segala sesuatu yang baru dan kompleksitas yang ada. Kedua pengertian diatas sama-sama menekankan bahwa pembelajaran berbasis masalah merupakan kemampuan untuk dapat menghadapi setiap permasalahan yang dihadapi. Tan menegaskan bahwa pembelajaran berbasis masalah merupakan inovasi dalam pembelajaran karena dalam PBM kemampuan berpikir siswa betul-betul dioptimalisasikan melalui proses kerja kelompok atau tim yang sistematis,sehingga siswa dapat memberdayakan, mengasah, menguji, dan 
mengembangkan kemampuan berpikirnya secara berkesinambungan, (Rusman, 2010: 229). Hal serupa juga diungkapkan oleh Arends (1997) dalam Trianto (2009: 92) bahwa pengajaran berdasarkan masalah merupakan suatu pendekatan pembelajaran dimana siswa mengerjakan permasalahan yang autentik dengan maksud untuk menyusun pengetahuan mereka sendiri, mengembangkan inkuiri dan keterampilan berpikir tingkat tinggi, mengembangkan kemandirian dan percaya diri.

Tabel 1

Langkah-langkah Pembelajaran Berbasis Masalah

\begin{tabular}{|c|l|l|}
\hline Fase & \multicolumn{1}{|c|}{ Indikator } & \multicolumn{1}{|c|}{ Tingkah Laku Guru } \\
\hline 1 & Orientasi siswa pada masalah & $\begin{array}{l}\text { Menjelaskan Tujuan Bembelajaran, dan } \\
\text { memotivasi siswa terlibat pada aktivitas } \\
\text { pemecahan masalah }\end{array}$ \\
\hline 2 & $\begin{array}{l}\text { Mengorganisasi siswa untuk } \\
\text { belajar }\end{array}$ & $\begin{array}{l}\text { Membantu siswa mendefinisikan dan mengorga } \\
\text { nisasikan tugas belajar yang berhubungan } \\
\text { dengan masalah tersebut }\end{array}$ \\
\hline 3 & $\begin{array}{l}\text { Membimbing pengalaman } \\
\text { individu/kelompok }\end{array}$ & $\begin{array}{l}\text { Mendorong siswa untuk mengumpulkan } \\
\text { informasi yang sesuai, melaksanakan } \\
\text { eksperimen untuk mendapatkan penjelasan dan } \\
\text { pemecahan masalah }\end{array}$ \\
\hline 5 & $\begin{array}{l}\text { Mengembangkan dan } \\
\text { menyajikan hasil karya }\end{array}$ & $\begin{array}{l}\text { Membantu siswa dalam merencanakan dan } \\
\text { menyiapkan karya yang sesuai seperti laporan, } \\
\text { dan membantu mereka untuk berbagai tugas } \\
\text { dengan temannya }\end{array}$ \\
\hline $\begin{array}{l}\text { Menganalisis dan } \\
\text { pemecahan masalah }\end{array}$ & $\begin{array}{l}\text { Membantu siswa untuk melakukan refleksi atau } \\
\text { evaluasi terhadap penyelidikan mereka dan } \\
\text { proses yang mereka gunakan }\end{array}$ \\
\hline
\end{tabular}

(Rusman, 2010: 243).

\section{Metode}

Jenis penelitian ini adalah penelitian eksperimen. Penelitian ini akan melibatkan dua kelompok yakni kelompok eksperimen dan kelompok kontrol yang dipilih dengan menggunakan teknik class random sampling.

Penelitian ini dilaksanakan di kelas VIII MTs Negeri 3 Wakatobi di Binongko. Waktu pelaksanaan penelitian telah dilakukan pada semester ganjil tahun ajaran 2018/2019 pada materi sistem persamaan linear dua variabel.

Populasi dalam penelitian ini adalah seluruh siswa kelas VIII di MTs Negeri 3
Wakatobi di Binongko tahun ajaran 2018/2019, yang tersebar dalam 3 kelas, yaitu kelas $\mathrm{VIII}_{1}$, $\mathrm{VIII}_{2}$ dan $\mathrm{VIII}_{3}$ yang terdiri dari 59 siswa. Berdasarkan wawancara dengan guru di sekolah, diperoleh informasi bahwa siswa kelas VIII MTs Negeri 3 Wakatobi terdiri dari tiga kelas tanpa ada kelas unggulan, yang tersebar secara heterogen, dalam arti bahwa secara umum dalam masing masing kelas terdapat siswa yang berkemampuan tinggi, sedang, dan rendah. Secara rinci populasi penelitian dapat dilihat pada tabel berikut.

Tabel 2

Distribusi Populasi Siswa Kelas VIII di MTs Negeri 3 Wakatobi di Binongko

\begin{tabular}{|c|c|c|}
\hline Kelas & Jumlah & Nilai Rata-Rata \\
\hline $\mathrm{VIII}_{1}$ & 20 & 63,8 \\
\hline $\mathrm{VIII}_{2}$ & 19 & 62,7 \\
\hline $\mathrm{VIII}_{3}$ & 20 & 59,5 \\
\hline
\end{tabular}

Sampel dalam penelitian ini dipilih sampling. Dari teknik pengambilan sampel dengan menggunakan teknik class random tersebut, kemudian diperoleh kelas $\mathrm{VIII}_{1}$ sebagai 
kelas eksperimen dan kelas $\mathrm{VIII}_{2}$ sebagai kelas kontrol.

Penelitian ini menggunakan desain Posttest-only Control group design. dimana dua kelas sampel ditetapkan secara acak, kemudian diberikan perlakuan yang berbeda. Kelas pertama adalah kelas eksperimen dan kelas yang kedua adalah kelas kontrol. Pada keduanya diberikan posttest. Desain penelitian tersebut dinyatakan sebagai berikut.

\section{Desain Penelitian}

\begin{tabular}{|c|c|c|}
\hline Kelas & Perlakuan & Posttest \\
\hline Eksperimen & $\mathrm{X}_{1}$ & $\mathrm{Y}_{1}$ \\
\hline Kontrol & $\mathrm{X}_{2}$ & $\mathrm{Y}_{2}$ \\
\hline
\end{tabular}

(Suryabrata dalam Qulfasian, 2015: 39)

Keterangan :

$\mathrm{X}_{1}$ : pembelajaran matematika dengan model pembelajaran berbasis masalah.

$\mathrm{X}_{2}$ : pembelajaran matematika dengan model pembelajaran konvensional.

$\mathrm{Y}_{1}$ : hasil belajar kognitif matematika siswa setelah menerapkan model pembelajaran berbasis masalah.

$\mathrm{Y}_{2}$ : hasil belajar kognitif matematika siswa setelah menerapkan model pembelajaran konvensional.

Penelitian ini mempunyai dua instrumen, yaitu instrumen berupa lembar observasi kegiatan guru dan aktivitas siswa dan instrument hasil belajar kognitif matematika siswa.

Untuk mengukur tingkat aktivitas/partisipasi guru dan siswa dalam proses pembelajaran matematika dengan menggunakan model pembelajaran berbasis masalah, dalam penelitian ini digunakan instrumen berupa lembar observasi, yakni lembar observasi untuk guru dan lembar observasi untuk siswa. Lembar observasi ini digunakan pada setiap pertemuan, yaitu sebanyak 5 kali pertemuan. Lembar pengamatan yang dibuat terdiri dari beberapa aspek observasi yang bertujuan untuk mengontrol setiap tindakan/aktivitas yang dilakukan oleh guru dan siswa dalam kelas, selama proses pembelajaran berlangsung, persiapan materi pembelajaran, serta teknik yang digunakan guru dalam menerapkan model pembelajaran berbasis masalah.
Dalam penelitian ini peneliti menggunakan instrumen tes berupa soal bentuk uraian untuk mengukur hasil belajar kognitif siswa. Tes uraian adalah suatu tes yang meminta siswa untuk mengingat dan mengorganisasi gagasan atau hal hal yang telah dipelajarinya dengan cara mengemukakan atau mengekspresikannya dalam bentuk uraian tertulis, Ahiri(2011:32). Menggunakan soal bentuk uraian dikarenakan soal bentuk uraian dapat digunakan untuk mengukur kegiatankegiatan belajar yang sulit diukur oleh soal dalam bentuk objektif. Peneliti menggunakan bentuk uraian dengan tujuan agar siswa dapat menguraikan dan menyatakan jawaban dengan kata-kata sendiri dalam bentuk, teknik dan gaya yang berbeda satu dengan yang lainnya.

Sebelum pedoman tes yang berupa soalsoal tes ini digunakan, terlebih dahulu peneliti mengujicobakannya untuk memastikan validitas dan reliabilitas soal tes. Sehingga diharapan soal yang digunakan benar-benar dapat mengukur hasil belajar kognitif siswa.

Validitas adalah suatu ukuran yang menunjukkan tingkat kesahihan atau kevalidan suatu instrumen. Untuk tes uraian, validitas butir tesnya dihitung dengan menggunakan rumus KorelasiProduct Moment dengan angka kasar sebagai berikut:

$$
r_{X Y}=\frac{N \sum X Y-\left(\sum X\right)\left(\sum Y\right)}{\sqrt{\left.\left\{N \sum X^{2}-\left(\sum X\right)^{2}\right\} N \sum Y^{2}-\left(\sum Y\right)^{2}\right\}}}
$$

(Sudjono, 2009:206)

\section{Keterangan:}

$\mathrm{r}_{\mathrm{XY}}=$ koefisian validitas

$\mathrm{X}=$ skor tiap butir soal

$\mathrm{Y}=$ skor total

$\mathrm{N}=$ jumlah subyek

Adapun kriteria pengujian sebagai

berikut:

a. Jika $\mathrm{r}_{\mathrm{xy}} \geq r_{\text {tabel }}$ dengan $\alpha=0,05$ maka item tersebut valid

b. Jika $\mathrm{r}_{\mathrm{xy}}<r_{\text {tabel }}$ dengan $\alpha=0,05$ maka item tersebut tidak valid

Sebelum posttest diberikan kepada siswa kelas VIII MTs Negeri 3 Wakatobi, terlebih dahulu dilakukan uji coba untuk mengetahui layak tidaknya perangkat tes digunakan untuk mengukur hasil belajar kognitif 
matematika siswa pada materi Sistem Persamaan Linear Dua Variabel.

Tabel 3

Hasil Analisis Validitas Posttest Hasil Belajar Kognitif Matematika Siswa

\begin{tabular}{|c|c|c|c|}
\hline Nomor Soal & $\boldsymbol{r}_{\text {hitung }}$ & $\boldsymbol{r}_{\text {tabel }}$ & Kriteria \\
\hline 1 & 0,526 & 0,433 & Valid \\
\hline 2 & 0,864 & 0,433 & Valid \\
\hline 3 & 0,654 & 0,433 & Valid \\
\hline 4 & 0,615 & 0,433 & Valid \\
\hline 5 & 0,400 & 0,433 & Invalid \\
\hline
\end{tabular}

Berdasarkan Tabel 3 validitas tiap butir soal ditunjukkan pada kolom total baris pertama pada masing-masing butir soal. Uji coba dilakukan pada 20 responden dengan $\mathrm{r}_{\text {tabel }}$ uji dua arah dengan tingkat kepercayaan 95\% adalah 0,433 . Berdasarkan tabel di atas, terdapat 4 butir soal yang valid yaitu butir $1,2,3$, dan 4 , sebab $r_{\text {hitung }}>r_{\text {tabel }}$ dan terdapat 1 soal yang tidak valid yaitu butir 5 sebab $r_{\text {hitung }}<r_{\text {tabel }}$.

Reliabilitas berarti sejauh mana hasil suatu pengukuran dapat dipercaya. Seperangkat tes dikatakan reliabel apabila tes tersebut dapat memberikan hasil yang tetap. Artinya jika tes tersebut dikenakan pada sejumlah subjek yang sama pada lain waktu, maka hasilnya akan tetap sama atau relatif sama. Untuk menghitung reliabilitas tes bentuk uraian digunakan rumus Alpha Cronbach sebagai berikut.

$$
r_{11}=\frac{n}{n-1}\left(1-\frac{\Sigma \sigma_{\mathrm{i}}^{2}}{\sigma_{t}^{2}}\right)
$$

Dengan rumus varian, yaitu:

$$
\sigma_{i}^{2}=\frac{\Sigma \mathrm{X}^{2}-\frac{\left(\Sigma X_{i}\right)^{2}}{N}}{N}
$$

Keterangan:

$r_{11} \quad$ : reliabilitas instrumen

$n$ : banyaknya butir soal

$\sum \sigma_{i}^{2}$ : jumlah varian semua butir soal

$\sigma_{t}^{2} \quad$ : varians total

$N$ : banyak siswa

$\Sigma X^{2} \quad$ : jumlah skor total kuadrat

$\left(\sum X\right)^{2}$ : kuadrat jumlah skor (Arikunto dalam

Rohman, 2007: 112).

Hasil perhitungan koefisien reliabitas terhadap data uji coba Posttest hasil belajar kognitif matematika dapat dilihat sebagai berikut.

\section{Hasil Analisi Reliabilitas Posttest Hasil Belajar Kognitif Matematika Siswa Reliability Statistics}

\begin{tabular}{|c|c|}
\hline $\begin{array}{c}\text { Cronbach' } \\
\text { Alpha }\end{array}$ & N of items \\
\hline 0,565 & 4 \\
\hline Diperoleh koefisien reliabilitasnya
\end{tabular}
sebesar 0,656 yang dapat diinterpretasikan dalam kategori sedang. Hal ini berarti bahwa instrumen ini cukup tetap atau cukup baik digunakan untuk mengukur hasil belajar kognitif matematika siswa.

Teknik pengumpulan data dalam penelitian ini akan dilakukan dengan lembar observasi yang digunakan untuk pengamatan dan tes untuk mengukur hasil belajar kognitif matematika siswa. Pengumpulan data dalam penelitian ini dilakukan dengan pemberian instrument berupa tes hasil belajar kognitif matematika siswa berbentuk essay/uraian sebanyak 4 nomor kepada siswa. Pada setiap pertemuan observer akan mengamati kegiatan pembelajaran di kelas melalui lembar observasi. Hasilnya akan dipergunakan untuk memperoleh data tentang aktivitas atau partisipasi guru dan siswa.

Tes hasil belajar kognitif matematika, dilakukan pada pertemuan terakhir (posttest) pada kelas eksperimen dan kelas kontrol. Kemudian tes tersebut dikerjakan oleh siswa, masing-masing soal yang telah dikerjakan diberikan skor berdasarkan sistematika proses pengerjaannya. Selanjutnya, hasil pekerjaan siswa dikumpulkan oleh peneliti untuk diperiksa dan diberi skor.

Analisis data dalam penelitian ini menggunakan analisis deskriptif dan analisis inferensial. Analisis deskriptif digunakan untuk 
memberikan gambaran tentang karakteristik aktivitas belajar siswa. Analisis deskriptif juga dimaksudkan untuk mendeskripsikan hasil belajar kognitif matematika siswa melalui nilai rata-rata $(\bar{x})$, median $(\mathrm{Me})$, modus(Mo), varians $\left(\mathrm{S}^{2}\right)$, standar deviasi $(\mathrm{S})$, nilai maksimum $\left(\mathrm{X}_{\max }\right)$, nilai minimum $\left(\mathrm{X}_{\mathrm{min}}\right)$, skewness dan kurtosis yang diperoleh dengan bantuan SPSS. Analisis inferensial digunakan menguji hipotesis penelitian. Sebelum dilakukan pengujian hipotesis, terlebih dahulu melalui tahapan uji prasyarat untuk melakukan uji hipotesis, yaitu uji normalitas dan uji homogenitas. Uji apakah data yang diperoleh berasal dari populasi yang berdistribusi normal atau tidak. Untuk keperluan ini, maka uji statistik yang digunakan adalah Uji Kolmogorov-Smirnov dengan bantuan SPSS. Sedangkan Jika data yang diperoleh berasal dari populasi yang berdistribusi normal, maka dilanjutkan dengan dimaksudkan untuk mengetahui apakah varians data kedua kelompok yang diteliti mempunyai varians yang homogen atau tidak. Uji normalitas data dimaksudkan untuk mengetahui uji homogenitas. Uji homogenitas data

homogenitas dilakukan apabila kelompok data normal. Adapun uji homogen tidak perlu dilakukan apabila dua kelompok data atau lebih mempunyai varians yang sama besar. Dalam pengujian ini untuk menguji apakah data mempunyai varians yang sama atau tidak digunakan uji-Levene dengan menggunakan Aplikasi Matematika SPSS. Dan Setelah pengujian populasi data telah dilakukan menggunakan uji normalitas dan uji homogenitas, maka akan dilakukan pengujian hipotesis dengan uji-t, untuk mengetahui adanya perbedaan antara hasil belajar kognitif matematika siswa yang diajarkan dengan menggunakan model pembelajaran berbasis masalah dengan siswa yang diajarkan menggunakan model pembelajaran konvensional.

\section{Hasil}

Hasil analisis deskriptif data hasil belajar kognitif matematika siswa kelas eksperimen dan kelas kontrol menggunakan bantuan aplikasi IBM SPSS Statistics, dapat dilihat pada Tabel berikut.

Tabel 4

Diskripsi Hasil Belajar Kognitif Matematika Siswa Kelas Eksperimen dan Kelas Kontrol

\begin{tabular}{|c|c|c|}
\hline \multicolumn{3}{|l|}{ Statistics } \\
\hline & Kelas Eksperimen & Kelas Kontrol \\
\hline Minimum & 69.44 & 61.11 \\
\hline Maximum & 88.89 & 83.33 \\
\hline Mean & 80.4167 & 70.0292 \\
\hline Median & 80.5556 & 69.4444 \\
\hline Modus & 80.56 & 69.44 \\
\hline Std. Deviation & 5.73362 & 5.75111 \\
\hline Variance & 32.874 & 33.075 \\
\hline Sum & 1608.33 & 1330.56 \\
\hline Skewness & $-0,484$ & 0,777 \\
\hline Kurtosis & $-0,319$ & 0,430 \\
\hline
\end{tabular}

a. Analisis Deskriptif Hasil Belajar Kognitif Berbasis Masalah

Matematika Siswa yang Pembelajarannya Menggunakan Model Pembelajaran 


\section{Jurnal Penelitian Pendididikan Matematika Volume 7 No.2 Mei 2019}

Setelah dilaksanakan proses pembelajaran pada materi Sistem Persamaan Linear Dua Variabel dengan mengggunakan model pembelajaran berbasis masalah seperti yang terlihat pada Tabel 4, nilai rata-rata yang diperoleh siswa di kelas eksperimen adalah 80.42 dari 20 siswa. Sedangkan modus yaitu nilai yang jumlahnya paling banyak diperoleh siswa dari tes hasil belajar adalah 80.56. Berdasarkan data tersebut diperoleh karakteristik statistik dengan nilai minimum yaitu nilai terendah yang diperoleh siswa dikelas ekperimen adalah 69.44 dan nilai maksimum yaitu nilai tertinggi yang diperoleh siswa di kelas eksperimen adalah 88.89. Sum atau jumlah dari posttest kelas eksperimen sebesar 1608.33. Median atau nilai tengah dari data tersebut adalah 80.55 artinya $50 \%$ siswa memperoleh nilai di bawah 80.55 dan $50 \%$ siswa memperoleh nilai di atas 80.55. Standar deviasi dari data tersebut adalah 5.73, artinya data hasil belajar siswa cenderung heterogen, varians yaitu kuadrat dari standar deviasi sebesar 32.874, Skewness(Kemiringan) dari data tersebut adalah $-0,484$ dan Kurtosis dari data tersebut adalah $-0,319$.

b. Analisis Deskriptif Hasil Belajar Kognitif Matematika Siswa pada Kelas yang Menggunakan Model Pembelajaran Konvensional

Setelah dilaksanakan proses pembelajaran pada materi Sistem Persamaan Linear Dua Variabel dengan menggunakan model pembelajaran konvensional seperti yang terlihat pada Tabel 4, nilai rata-rata yang diperoleh siswa di kelas kontrol adalah 70.03 dari 19 siswa. Sedangkan modus yaitu nilai yang jumlahnya paling banyak diperoleh siswa dari tes hasil belajar adalah 69.44. Berdasarkan data tersebut diperoleh karakteristik statistik dengan nilai minimum yaitu nilai terendah yang diperoleh siswa di kelas kontrol adalah 61.11 dan nilai maksimum yaitu nilai tertinggi yang diperoleh siswa di kelas kontrol adalah 83.33. Sum atau jumlah yang diperoleh dari data posttest kelas kontrol adalah 1330.56. Median atau nilai tengah dari data tersebut adalah 69.44 artinya $50 \%$ siswa memperoleh nilai di bawah 69.44 dan $50 \%$ siswa memperoleh nilai di atas
69.44. Standar deviasi dari data tersebut adalah 5.75, maksudnya data hasil belajar siswa cenderung heterogen, varians yaitu kuadrat dari standar deviasinya sebesar 33.075, Skweness (Kemiringan) dari data tersebut adalah 0,777 dan Kurtosis dari data tersebut adalah 430.

Selanjutnya Hasil Analisis Inferensial Sebelum dilakukan pengujian hipotesis terlebih dahulu dilakukan uji normalitas dan uji homogenitas. Uji normalitas data dilakukan untuk mengetahui apakah data berasal dari populasi yang berdistribusi normal atau tidak. Uji homogenitas (kelas eksperimen dan kelas kontrol) dilakukan untuk mengetahui apakah varians dari kedua data homogen atau tidak. Hal tersebut dilakukan untuk keperluan penentuan uji hipotesis yang akan dipilih.

\section{Data Kelas Eksperimen}

Perhitungan uji normalitas data kelas eksperimen diolah menggunakan aplikasi SPSS dengan menggunakan uji Kolmogorov-Smirnov, diperoleh nilai Sig. $=0,688>\alpha=0,05$ Berdasarkan hal tersebut, dapat disimpulkan bahwa hasil belajar kognitif (posttest) matematika siswa pada kelas eksperimen yang diajar dengan menggunakan model pembelajaran berbasis masalah pada materi sistem persamaan linear dua variabel berdistribusi normal.

\section{Data Kelas Kontrol}

Sedangkan Uji normalitas data kelas kontrol yang diajar dengan menggunakan model pembelajaran konvensional diolah menggunakan program SPSS diperoleh dengan menggunakan uji Kolmogorov-Smirnov, menunjukkan bahwa nilai Sig. $=0,293>\alpha=0,05$. Berdasarkan nilai tersebut, dapat disimpulkan bahwa hasil belajar kognitif (posttest) matematika siswa pada kelas kontrol yang diajar dengan menggunakan model pembelajaran konvensional pada materi sistem persamaan linear dua variabel berdistribusi normal.

Berikut ini adalah hasil analisis uji normalitas data hasil belajar kognitif (posttest) pada kedua kelas (Eksperimen dan Kontrol) tersebut dapat dilihat pada Tabel sebagai berikut. 
Tabel 5

Hasil Analisis Uji Normalitas Data Posttest pada Kedua Kelas

\begin{tabular}{|l|l|l|l|}
\hline \multicolumn{2}{|l|}{} & Eksperimen & Kontrol \\
\hline N & 20 & 19 \\
\hline \multirow{3}{*}{ Normal Parameters } & Mean & 80.4167 & 70.0292 \\
\cline { 2 - 4 } & Std. Deviation & 5.73362 & 5.75111 \\
\hline \multirow{2}{*}{$\begin{array}{l}\text { Most Extreme } \\
\text { Difference }\end{array}$} & Absolute & 0.160 & 0.225 \\
\cline { 2 - 4 } & Positive & 0.090 & 0.225 \\
\cline { 2 - 4 } & Negative & -0.160 & -0.091 \\
\hline Kolmogorov-Smirnov Z & 0.714 & 0.979 \\
\hline Asymp. Sig. (2-tailed) & 0.688 & 0.293 \\
\hline
\end{tabular}

Berdasarkan Tabel di atas dapat disimpulkan bahwa data hasil belajar kognitif (posttest) matematika siswa pada kelas eksperimen yang diajar menggunakan model pembelajaran berbasis masalah maupun pada kelas kontrol yang diajar menggunakan model pembelajaran konvensional pada materi sistem persamaan linear dua variabel berdistribusi normal.
Uji homogenitas varians digunakan untuk mengetahui apakah varians dari kedua kelompok data tes hasil belajar kognitif matematika siswa homogen atau tidak. Berdasarkan hasil uji homogenitas varians data dari kedua kelompok sampel dengan bantuan IBM SPSS Statistics. Hasil perhitungan dapat dilihat pada Tabel berikut.

Tabel 6

Hasil Analisis Uji Homogenitas Varians

Data Posttest

\begin{tabular}{|l|l|l|l|}
\hline \multicolumn{4}{|l|}{ Test of Homogeneity of Variances } \\
\hline KPM & & & \\
\hline $\begin{array}{l}\text { Levene } \\
\text { Statistic }\end{array}$ & df1 & df2 & Sig. \\
\hline .001 & 1 & 37 & .974 \\
\hline
\end{tabular}

Berdasarkan hasil analisis uji homogenitas varians diperoleh nilai Sig $=0,974$. Karena nilai $\mathrm{Sig}=0,974>0.05=\alpha$ maka $\mathrm{H}_{0}$ diterima, hal ini berarti bahwa data yang diperoleh memiliki varians yang homogen.
Pengujian hipotesis menggunakan uji-t data sampel saling bebas (Independent Sample $t$-test) dilakukan dengan rumus uji-t menggunakan IBM SPSS Statistics .

Adapun hasil analisis uji hipotesis dapat dilihat pada Tabel berikut. berikut. 
Tabel 7

Hasil Analisis Uji Hipotesis

\begin{tabular}{|l|l|l|l|l|l|l|}
\hline \multicolumn{2}{|l|}{} & \multicolumn{2}{l|}{$\begin{array}{l}\text { Levene's Test } \\
\text { for Equality of } \\
\text { Variances }\end{array}$} & \multicolumn{2}{|l|}{ t-test for Equality of Means } \\
\cline { 2 - 7 } & F & Sig. & T & Df & Sig. (2-tailed) \\
\hline KPM & $\begin{array}{l}\text { Equal variances } \\
\text { assumed }\end{array}$ & .001 & .974 & 5.647 & 37 & .000 \\
\hline
\end{tabular}

Berdasarkan hasil analisis uji-t diperoleh $\mathrm{t}_{\text {hitung }}=5,647>$ nilai $\quad \mathrm{t}_{\text {tabel }}=1,68709$ atau nilai $\frac{\operatorname{Sig}(2-\text { tailed })}{2}=\frac{0,000}{2}=0,000<0,05$, maka $\mathrm{H}_{0}$ ditolak. Dengan ditolaknya $\mathrm{H}_{0}$, maka dapat disimpulkan bahwa hasil belajar kognitif matematika siswa meningkat. Hal ini menunjukan adanya pengaruh yang signifikan model pembelajaran berbasis masalah terhadap hasil belajar kognitif matematika siswa kelas VIII MTs Negeri 3 Wakatobi di Binongko.

\section{Pembahasan}

Penelitian ini dilakukan di MTs Negeri 3 Wakatobi di Binongko pada kelas VIII. Penelitian ini terdiri atas dua kelas penelitian yaitu kelas eksperimen dan kelas kontrol. Kelas eksperimen diajar dengan menggunakan model pembelajaran berbasis masalah sedangkan kelas kontrol diajar dengan menggunakan model pembelajaran konvensional. Pada penelitian ini, kelas yang diajar dengan model pembelajaran berbasis masalah adalah kelas $\mathrm{VIII}_{1}$ sebanyak 20 siswa, sedangkan kelas yang diajar dengan menggunakan model pembelajaran konvensional adalah kelas $\mathrm{VIII}_{2}$ sebanyak 19 siswa. Waktu pembelajaran dalam pelaksanaan penelitian pada setiap pekan adalah 5 jam pelajaran. Sedangkan untuk tiap pertemuan Alokasi waktunya berbeda, yaitu $3 \times 40$ menit dan $2 \times 40$ menit. Kedua kelas diberikan waktu $3 \times 40$ menit(120) pada pertemuan ketujuh yang digunakan untuk pelaksanaan Posttest hasil belajar kognitif matematika siswa. Sebelum diberikan post test, diberikan perlakuan berupa model pembelajaran berbasis masalah pada kelas eksperimen dan model pembelajaran konvensional pada kelas kontrol, dengan materi yang sama yaitu materi sistem persamaan linear dua variabel.

Model pembelajaran yang diterapkan pada kelas eksperimen adalah pembelajaran berbasis masalah yang memiliki lima tahap pembelajaran yaitu: orientasi siswa pada masalah, mengorganisasikan siswa untuk belajar, membimbing pengalaman individu atau kelompok, mengembangkan dan menyajikan hasil karya, dan menganalisis dan mengevaluasi pemecahan masalah. Tahap-tahap tersebut menekankan kepada siswa agar mampu menyelesaikan suatu masalah dengan kemampuan berpikirnya sendiri, sehingga siswa jadi terlatih untuk mengembangkan hasil belajar kognitif matematika mereka dalam memecahkan masalah matematika.

Proses pembelajaran dimulai dengan kegiatan pendahuluan berupa pemberian apersepsi, dilanjutkan dengan pemberian contoh masalah kontekstual yang berhubungan dengan materi sistem persamaan linear dua variabel. Kemudian guru membagi siswa ke dalam 4 kelompok belajar yang masing-masing terdiri atas 5 siswa berkemampuan heterogen. Setiap kelompok diberikan bahan ajar dan LKPD. Pada tahap ini, apabila ada siswa yang bertanya maka guru akan berperan untuk mengarahkan dan membimbing siswa melalui penjelasan atau pertanyaan yang mengarah pada penyelesaian masalah. Setelah setiap kelompok menyelesaikan permasalahan dari LKPD sesuai dengan waktu yang telah ditetapkan, beberapa siswa dipilih sebagai perwakilan dari kelompoknya untuk mempresentasikan hasil diskusi kelompok mereka kemudian ditanggapi oleh kelompok lain. Guru berperan memandu 
jalannya diskusi, meluruskan jika ada jawaban siswa yang keliru dan membantu siswa dalam mengambil kesimpulan jawaban yang benar dari hasil pemecahan masalah yang dibuat masingmasing kelompok. Pada akhir pertemuan, guru bersama siswa melakukan refleksi lalu guru akan membimbing siswa menyimpulkan materi yang telah dipelajari.

Berdasarkan lembar observasi, persentase pengelolaan pembelajaran oleh guru pernah mencapai $100 \%$ dalam lima kali pertemuan. Hal Ini menandakan bahwa penerapan model pembelajaran berbasis masalah bukanlah hal mudah terutama bagi siswa. Pada pelaksanaan pembelajaran, ada langkah-langkah yang direncanakan tidak dapat dilaksanakan dengan maksimal pula tidak jarang soal yang dihadapi siswa tidak dapat diselesaikan dengan baik. Hal ini disebabkan oleh kurang mampunya siswa dalam menyelesaikan masalah-masalah yang membutuhkan hasil belajar kognitif matematika. Apabila siswa kesulitan menyelesaikan masalah sampai mengalami kekeliruan atau bahkan sama sekali tidak tahu, guru menjelaskan proses penyelesaian masalah di papan tulis.

Pada pertemuan pertama pula peneliti mengalami hambatan dalam pelaksanaan pembelajaran karena siswa masih belum terbiasa dengan model pembelajaran yang baru diterima. Pada saat pembagian kelompok ada beberapa siswa yang menimbulkan suasana gaduh lantaran mereka belum terbiasa beradaptasi dengan kelompoknya, sehingga proses ini cukup menyita waktu pembelajaran. Siswa yang tidak terbiasa dalam diskusi kelompok cenderung tidak antusias dan kurang kooperatif dalam pembelajaran ini. Siswa masih membutuhkan waktu untuk menyesuaikan diri dengan pembelajaran yang baru diterapkan di kelas, sehingga ada beberapa kelompok yang masih sulit untuk berdiskusi dalam hal menyelesaikan masalah yang terdapat pada LKPD. Sebagian besar juga belum percaya diri dalam mengeluarkan pendapat ataupun mengeluarkan pertanyaan, serta guru juga masih menyesuaikan diri dengan kondisi kelas. Hal ini mengakibatkan proses penyerapan materi pembelajaran oleh siswa kurang maksimal.

Pada pertemuan kedua dan pertemuanpertemuan berikutnya, proses pembelajaran berjalan dengan baik dan lancar. Siswa juga mulai memahami setiap tahap dalam model pembelajaran berbasis masalah yang diterapkan di kelas. Hal ini didukung dengan persentase ketercapaian aspek yang diamati yang secara keseluruhan meningkat dari tiap pertemuan dimana siswa telah menunjukan sikap antusias dalam pembelajaran dan mulai merasa bertanggung jawab dalam menyelesaikan masalah pada LKPD yang diberikan. Siswa yang tadinya membutuhkan pengarahan guru dalam memberikan kesimpulan juga mulai mampu memberikan kesimpulan secara mandiri meski belum sepenuhnya.

Berdasarkan hasil observasi aktivitas guru dalam pelaksanaan pembelajaran dapat dikatakan bahwa pencapaian keterlaksanaan pembelajaran tergolong berhasil. Adapun hasil observasi keaktifan siswa, dapat dikatakan bahwa pencapaian keterlaksanaan pembelajaran ditiap pertemuan terus meningkat dan menunjukkan tanda-tanda siswa memenuhi kriteria kompetensi inti yang diinginkan. Setelah proses pembelajaran selesai, pada pertemuan ke enam diberikan posttest. Kemudian, data hasil posttest tersebut diolah menggunakan SPSS untuk menguji apakah model pembelajaran berbasis masalah memberikan pengaruh pada hasil belajar kognitif matematika siswa kelas VIII MTs Negeri 3 Wakatobi.

Berdasarkan hasil analisis deskriptif dari data yang diperoleh melalui tes hasil belajar kognitif matematika siswa, diperoleh bahwa nilai rata-rata hasil belajar kognitif siswa yang diajar dengan menggunakan model pembelajaran berbasis masalah sebesar 80,42. Sedangkan nilai rata-rata hasil belajar kognitif siswa yang diajar dengan menggunakan

model pembelajaran konvensional sebesar 70,03 . Hal ini menunjukkan bahwa nilai hasil belajar kognitif siswa yang diajar dengan menggunakan model pembelajaran berbasis masalah memiliki nilai rata-rata hasil belajar kognitif yang lebih tinggi daripada rata-rata hasil belajar siswa yang diajar dengan menggunakan model pembelajaran konvensional. Dari segi standar deviasi, kelas eksperimen memiliki nilai standar deviasi sebesar 5,73 sedangkan kelas kontrol memiliki standar deviasi sebesar 5,75. Hal ini menunjukkan bahwa data hasil belajar kognitif (posttest) kelas kontrol lebih beragam daripada kelas eksperimen. Median (nilai tengah) dari kelas eksperimen adalah 80,55, sedangkan median kelas kontrol adalah 69,44. Modus (nilai yang paling sering muncul) dari hasil posttest 
kelas eksperimen adalah 80,56, sedangkan modus kelas control adalah 69,44. Dilihat dari nilai minimum dan nilai maksimum, nilai minimum untuk kelas eksperimen adalah 69,44 dan nilai maksimumnya adalah 88,89. Sedangkan untuk kelas kontrol, nilai minimumnya sebesar 61,11 dan nilai maksimumnya sebesar 83,33. Skewness(kemiringan) pada kelas eksperimen bernilai negatif yakni -0,484 (Kemencengan negatif) dimana nilai modus lebih besar dari nilai mean(modus > mean), sedangkan pada kelas kontrol bernilai 0,777 (kemencengan positif) dimana nilai mean lebih besar dari nilai modus(mean > modus) dan Kurtosis pada kelas eksperimen bernilai -0,319 (platycurtic) karena nilai negatif berarti datanya tumpul atau cenderung melebar ke bawah, sedangkan pada kelas control bernilai 0,430 (leptokurtic) karena bernilai positif berarti datanya bersifat runcing atau cenderung mengelompok(homogen).

Data hasil belajar kognitif matematika siswa dalam penelitian ini diperoleh dari tes hasil belajar kognitif matematika siswa. Tes hasil belajar kognitif matematika siswa menggunakan soal yang sudah diuji validitas dan reliabilitasnya sehingga diperoleh nilai hasil belajar kognitif matematika siswa. Tes hasil belajar kognitif matematika siswa yang dimaksud adalah posttest.

1. Hasil Belajar Kognitif Matematika Siswa yang Pembelajarannya Menggunakan Model Pembelajaran Berbasis Masalah

Data hasil belajar kognitif matematika siswa diperoleh melalui tes hasil belajar kognitif pada materi sistem persamaan linear dua variabel. Tes tersebut diberikan pada siswa kelas eksperimen setelah diberikan perlakuan. Dimana kelas eksperimen ini menggunakan model pembelajaran berbasis masalah, sehingga diperoleh nilai hasil belajar kognitif matematika siswa dari hasil post test.

Hasil post test yang diperoleh merupakan gambaran hasil belajar kognitif matematika siswa, yang pembelajarannya menggunakan model pembelajaran berbasis masalah. Data hasil belajar kognitif tersebut diolah sehingga diperoleh nilai rata-rata hasil belajar kognitif matematika pada kelas eksperimen. Hasil analisis data diperoleh nilai rata-rata hasil belajar kognitif matematika siswa pada kelas eksperimen sebesar 80,42.
2. Hasil Belajar Kognitif Matematika Siswa yang Pembelajarannya Menggunakan Model Pembelajaran Konvensional

Data hasil belajar kognitif matematika siswa diperoleh melalui tes hasil belajar kognitif pada materi sistem persamaan linear dua variabel. Tes tersebut diberikan pada siswa kelas kontrol setelah diberikan perlakuan. Dimana kelas kontrol menggunakan model pembelajaran konvensional, sehingga diperoleh nilai hasil belajar kognitif matematika siswa dari hasil post test.

Hasil post test yang diperoleh merupakan gambaran hasil belajar kognitif matematika siswa yang pembelajarannya menggunakan model pembelajaran konvensional. Data hasil belajar kognitif tersebut diolah sehingga diperoleh nilai rata-rata hasil belajar kognitif matematika pada kelas kontrol. Hasil analisis data diperoleh nilai ratarata hasil belajar kognitif matematika siswa pada kelas kontrol sebesar 70,03.

Sebelum pengujian hipotesis, terlebih dahulu melakukan uji normalitas terhadap data posttest. Berdasarkan uji normalitas data dengan menggunakan uji Kolmogorov-Smirnov diperoleh hasil belajar kognitif posttest berdistribusi normal. Sehingga pengujian hipotesis dalam penelitian ini dilakukan dengan menggunakan Uji-t sampel berpasangan (Paired Sample t-test) uji satu pihak.

Berdasarkan hasil uji hipotesis dengan menggunakan uji-t diperoleh nilai $t_{\text {hitung }}=5,647$ $>$ nilai $\mathrm{t}_{\text {tabel }}=1,68709$ atau nilai $\frac{\operatorname{Sig}(2-\text { tailed })}{2}=$ $\frac{0,000}{2}=0,000<0,05$, yang berarti $\mathrm{H}_{0}$ ditolak. Dengan demikian kita dapat menarik suatu kesimpulan bahwa ada pengaruh yang siginifikan penggunaan model pembelajaran berbasis masalah terhadap hasil belajar kognitif matematika siswa kelas VIII MTs Negeri 3 Wakatobi di Binongko pada materi sistem persamaan linear dua variabel. Terjadinya peningkatan hasil belajar kognitif matematika siswa ini disebabkan oleh penggunaan model pembelajaran berbasis masalah. Model pembelajaran tersebut menuntut peran aktif siswa dan membantu siswa membangun pemahaman mendalam tentang bangunan pengetahuan sistematis dengan cara siswa dituntun dan diarahkan untuk lebih aktif dengan memberikan deskripsi menurut pemahamannya sendiri terkait materi yang diajarkan dan guru 
akan meluruskan penjelasan-penjelasan siswa yang masih keliru sehingga dapat meningkatkan hasil belajar kognitif matematika siswa.

Berdasarkan hasil analisis dalam penelitian ini, sebagian besar siswa mengalami peningkatan hasil belajar kognitif matematika pada kategori sedang dan tinggi. Kenyataan dalam penelitian ini menunjukkan bahwa model pembelajaran berbasis masalah dapat diterapkan dan dijadikan sebagai salah satu alternatif untuk membantu siswa dalam meningkatkan hasil belajar kognitif matematika siswa kelas VIII MTs Negeri 3 Wakatobi di Binongko.

\section{Simpulan dan Saran}

\section{Simpulan}

Berdasarkan penelitian dan pembahasan, maka dapat ditemukan kesimpulan sebagai berikut.

1. Proses pembelajaran dengan menggunakan model pembelajaran berbasis masalah pada kelas VIII MTs Negeri 3 Wakatobi terkategori sangat baik. Secara keseluruhan persentase tingkat keterlaksanaan pembelajaran oleh guru pada 5 kali pertemuan berturut-turut adalah $76 \%, 80 \%$, $84 \%, \quad 88 \%$ dan $100 \%$, Sedangkan persentase tingkat keaktifan siswa pada 5 kali pertemuan berturut-turut adalah $68.75 \%, 81.25 \%, 87.5 \%, 93.75 \%$, dan $100 \%$, persentase ini terkategori sangat baik dengan rata-rata persentase keaktifan siswa yang mengikuti pembelajaran dengan model pembelajaran berbasis masalah adalah $86.25 \%$.

2. Hasil belajar kognitif matematika siswa kelas VIII MTs Negeri 3 Wakatobi untuk kelas yang pembelajarannya menggunakan model pembelajaran berbasis masalah, memiliki nilai rata-rata sebesar 80,42 dengan kategori cukup, median sebesar 80,55 , modus sebesar 80,56, standar deviasi sebesar 5,73, varians sebesar 32,874, nilai maksimum sebesar 88,89 , nilai minimum sebesar 69,44 , skweness sebesar -0,484 dan kurtosis sebesar -0,319.

3. Hasil belajar kognitif matematika siswa kelas VIII MTs Negeri 3 Wakatobi untuk kelas yang pembelajarannya menggunakan model pembelajaran konvensional, memiliki nilai rata-rata sebesar 70,03 dengan kategori kurang baik, median sebesar 69,44, modus sebesar 69,44, standar deviasi sebesar 5,75, varians sebesar 33,075, nilai maksimum sebesar 83,33 , nilai minimum sebesar 61,11, skweness sebesar 0,777 dan kurtosis sebesar 0,430.

Berdasarkan hasil analisis Inferensial disimpulkan bahwa Adanya pengaruh yang signifikan model pembelajaran berbasis masalah terhadap hasil belajar kognitif matematika siswa kelas VIII MTs Negeri 3 Wakatobi di Binongko.

\section{Saran}

1. Kepada siswa, diharapkan untuk selalu aktif dan terlibat langsung dalam pembelajaran agar dapat memahami materi pembelajaran dengan baik.

2. Kepada guru, sebagai masukan dalam memberikan pelajaran matematika yang menekankan pada materi, hendaknya guru matematika dapat menciptakan kreasi yang menarik dan kreatif tanpa melupakan kebermaknaan materi pelajaran matematika salah satunya dengan memakai model pembelajaran berbasis masalah memudahkan siswa mengerti dan faham materi yang di ajarkan itu.

3. Kepada peneliti selanjutnya, perangkat pembelajaran dan tes hasil belajar matematika siswa yang terdapat pada penelitian ini dapat digunakan sebagai acuan dalam menerapkan model pembelajaran berbasis masalah.

\section{Daftar Pustaka}

Ahiri dan Hafid. (2011). Evaluasi Pembelajaran Dalam Konteks KTSP. Bandung: Humaniora.

Arikunto, S. (2007). Prosedur Penelitian Suatu Pendekatan Praktek Edisi Revisi VI. Rineka Apta. Jakarta.

Dasna, I. W. dan Sutrisno. (2007). Model-model Pembelajaran Inovatif. Malang: Lembaga Pengembangan Pendidikan dan Pembelajaran Universitas Negeri Malang.

Hadi, S. (2005). Pendidikan Matematika Realistik dan Implementasinya. Banjarmasi: Tulip. 
Hamalik, O. (2008). Kurikulum dan

Pembelajaran. Jakarta: Sinar Grafika.

Hudoyo, Herman. (2000). Pengembangan kurikulum dan Pembelajaran Matematika. Malang: Universitas Negeri Malang.

Indriyani, A. (2011). Efektivitas Model Pembelajaran Koopertif Tipe Team Assisted Individualization (TAI) Dan Think Pair Share (TPS) Ditinjau Dari Sikap Pecaya Diri Peserta Didik Pada Materi Limit Fungsi Kelas XI IPA SMA Kota Kediri tahun Pelajaran 2010/2011. Tesis Universitas Sebelas Maret: Tidak Diterbitkan.

Jihad,A. dan haris,A. (2008). Evaluasi Pembelajaran. Yogyakarta: Multi Pressindo

Mahendra, I Wawan Eka. (2007). Pengaruh Pembelajaran Kontekstual dan Gaya Berpikir Terhadap Prestasi Belajar Matematika. Singaraja: Undiksha.

Qulfasia, M. (2015). Pengaruh Model Pembelajaran ARIAS dengan Aetting Kooperatif JIGSAW Terhadap Hasil
Belajar Matematika Siswa Kelas VIII SMP Negeri 4 Kendari. Skripsi Universitas Halu Oleo: Tidak Diterbitkan.

Rusman. (2010). Model-Model Pembelajaran, Mengembangkan Profesionalisme Guru. Jakarta: PT RajaGrafindo Persada.

Sudjono, Anas. (2009). Pengantar Statistik Pendidikan. Jakarta. Raja Grafindo Persada.

Surya, Y. F. (2017). Penerapan Model Pembelajaran Problem Based Learning untuk Meningkatkan Hasil Belajar Matematika Siswa Kelas IV SDN 016 Langgini Kabupaten Kampar: Journal Cendekia: Jurnal Pendidikan Matematika, vol.1, No.1,38-53.

Trianto. (2009). Mendesain Model Pembelaaran Inovatif-Progresif. Jakarta: Kencana Perdana Media Group.

Winkel, W.S. (2007). Psikologi Pengajaran. Yogyakarta: Media Abadi. 